\title{
DE
} DE GRUYTER OPEN

\section{A COMPARISON OF THE FINANCIAL CHARACTERISTICS OF EUROPEAN AND ASIAN MANUFACTURING FIRMS}

Rohrer College of Business, Rowan University, Glassboro, New Jersey, USA

\section{WELSH Carol}

Rohrer College of Business, Rowan University, Glassboro, New Jersey, USA

\section{SCARPA Robert}

Rohrer College of Business, Rowan University, Glassboro, New Jersey, USA

\section{MERIC Ilhan}

Rohrer College of Business, Rowan University, Glassboro, New Jersey, USA

\begin{abstract}
:
Comparing the financial characteristics of firms in different countries has been a popular research topic in finance. However, general financial characteristics of European and Asian manufacturing firms have never been compared. In this paper, we undertake such a study with the MANOVA (Multivariate Analysis of Variance) technique. Our research uses all European and Asian manufacturing firms included in the Research Insight/Global Vintage database at the end of 2015. Our findings may provide valuable insights for financial managers and global investors. We find that Asian firms tend to have less liquidity risk but more bankruptcy risk compared with European firms. European firms have more efficient accounts receivable management and higher fixed and total assets turnover rates. However, Asian firms have higher inventory turnover and sales growth rates. Return on equity is not significantly different in European and Asian firms. However, Asian firms have significantly higher net profit margin and return on assets compared with European firms.
\end{abstract}

Key words: Financial ratios, European and Asian manufacturing firms, MANOVA (Multivariate Analysis of Variance)

\section{Introduction}

Comparing the financial characteristics of different groups of firms has long been a popular research methodology in finance literature. Altman (1968), Beaver (1968), Deakin (1972), Moyer (1977), Edmister (1972), and Dambolena and Khoury (1980) predict bankruptcy by comparing the financial characteristics of bankrupt and non-bankrupt firms. Stevens (1973), Belkaoui (1978), Rege (1984), and Meric at al. 
(1991) identify the financial characteristics of firms that have been corporate takeover targets by comparing them with firms that have not been corporate takeover targets. Hutchinson at al. (1988) and Meric and Meric (1992) identify the financial characteristics of firms which achieve stock market quotation by comparing them with firms that do not have stock market quotation. Meric at al. (2000) compare the financial characteristics of Japanese kieretsu-affiliated and independent firms to identify the financial characteristics of kieretsu-affiliated firms.

A number of studies compare the financial characteristics of firms in different countries. Kester (1986) and Wald (1999) compare the capital and ownership structures of firms in different countries and they find significant differences. Meric and Meric (1989 and 1994) compare the financial characteristics of U.S. and Japanese manufacturing firms and they find significant differences. Meric et al. (2003) find significant differences between the financial characteristics of U.S. and Canadian manufacturing firms. Meric et al. (2016) find significant differences between the financial characteristics of U.S. and European manufacturing firms.

To the best of our knowledge, general financial characteristics of European and Asian manufacturing firms have never been compared in previous studies. In this paper, we undertake such a study with a sample of all European and Asian manufacturing firms included in the Research Insight/Global Vintage Database at the end of 2015 by using the MANOVA (Multivariate Analysis of Variance) technique. The findings of such a study can provide valuable insights for financial managers in all countries and global investors.

\section{A Brief Description of European Economies}

The European Union (EU) provides a common platform for the economies of the European members of the EU. While the recent vote by the United Kingdom to exit the EU might bring some changes, at this point it is anticipated that the similarities and relationships will continue. The EU provides a single market for the country members with free movement of goods, services, and capital as it strives to provide a favorable climate for Europe's trade position and economic weight. The EU has a common currency - the euro- that currently is adopted by 19 of the member countries ( $\mathrm{ClA}$ World Fact Book, 2016).

The EU is made up of 28 European countries and, while there are significant differences in size of economy among the member countries, the three largest economies members of the EU are Germany, France, and the United Kingdom. The comparative economic statistics are provided in Tables 1a-1d. The EU has a Gross Domestic Product (GDP) per capita of $19,180.0$ billion dollars and is ranked second in the world. As the largest economies in the EU, based on Gross Domestic Product (GDP), Germany, France, and the UK make up $48 \%$ of the GDP of the EU. Individually, the three nations have similar GDP per capita ratios, with Germany's being higher than France and the UK, as seen in Table 1a. The EU represents a 
population of 513.9 million people and ranks third in the world. Population growth has been flat with a $0.25 \%$ rate and ranks 181 in the world.

Table 1a: Population, Growth Rate and Labor Force by Country and EU (2016 estimated)

\begin{tabular}{|c|c|c|c|c|c|}
\hline Country & $\begin{array}{l}\text { Population }^{1} \\
\text { [in millions] } \\
\text { (world rank) }\end{array}$ & $\begin{array}{l}\text { Population }^{2} \\
\text { Growth Rate } \\
\text { (world rank) }\end{array}$ & $\begin{array}{l}\text { Labor Force }{ }^{3} \\
\text { [in millions] } \\
\text { (world rank) }\end{array}$ & $\begin{array}{l}\text { Labor Force } \\
\text { as Percentage } \\
\text { of Population }\end{array}$ & $\begin{array}{l}\text { Unemployment } \\
\text { Rate } \\
\text { (world rank) }^{4}\end{array}$ \\
\hline $\begin{array}{l}\text { European } \\
\text { Union }\end{array}$ & $\begin{array}{l}513.9 \\
(3)\end{array}$ & $\begin{array}{l}0.25 \% \\
(181) \\
\end{array}$ & $\begin{array}{l}232.2 \\
(3)\end{array}$ & $45.2 \%$ & $\begin{array}{l}9.5 \% \\
(112) \\
\end{array}$ \\
\hline $\begin{array}{l}\text { United } \\
\text { Kingdom }\end{array}$ & $\begin{array}{l}64.4 \\
(23) \\
\end{array}$ & $\begin{array}{l}0.53 \% \\
(157) \\
\end{array}$ & $\begin{array}{l}33.0 \\
(19) \\
\end{array}$ & $51.2 \%$ & $\begin{array}{l}5.4 \% \\
(61) \\
\end{array}$ \\
\hline Germany & $\begin{array}{l}80.7 \\
(19) \\
\end{array}$ & $\begin{array}{l}-0.16 \%) \\
(211)\end{array}$ & $\begin{array}{l}45.0 \\
(15) \\
\end{array}$ & $55.8 \%$ & $\begin{array}{l}4.8 \% \\
(49) \\
\end{array}$ \\
\hline France & $\begin{array}{l}66.8 \\
(22) \\
\end{array}$ & $\begin{array}{l}0.41 \% \\
(160) \\
\end{array}$ & $\begin{array}{l}30.4 \\
(21) \\
\end{array}$ & $45.5 \%$ & $\begin{array}{l}10.10 \% \\
(118)\end{array}$ \\
\hline
\end{tabular}

${ }^{1}$ https://www.cia.gov/library/publications/resources/the-world-factbook/rankorder/2119rank.html ${ }^{2}$ https://www.cia.gov/library/publications/resources/the-world-factbook/rankorder/2002rank.html ${ }^{3} \mathrm{https} / / / \mathrm{ww} w . c i a . g o v / l i b r a r y / p u b l i c a t i o n s /$ resources/the-world-factbook/rankorder/2095rank.html ${ }^{4} \mathrm{https}: / / \mathrm{www}$. cia.gov/library/publications/resources/the-world-factbook/rankorder/2129rank.html

\section{Table 1b: GDP Composition by Sector of Origin (2015 estimated) ${ }^{1}$}

\begin{tabular}{|l||l|l|l|}
\hline \multicolumn{1}{|l||}{} & $\begin{array}{l}\text { Agriculture } \\
\text { Percent of Total } \\
\text { GDP }\end{array}$ & $\begin{array}{l}\text { Industry } \\
\text { Percent of } \\
\text { Total GDP }\end{array}$ & $\begin{array}{l}\text { Services } \\
\text { Percent of } \\
\text { Total GDP }\end{array}$ \\
\hline \hline European Union & $1.6 \%$ & $24.6 \%$ & $70.6 \%$ \\
\hline United Kingdom & $0.7 \%$ & $19.4 \%$ & $79.9 \%$ \\
\hline Germany & $0.6 \%$ & $30.4 \%$ & $69.0 \%$ \\
\hline France & $1.7 \%$ & $19.3 \%$ & $79.0 \%$ \\
\hline
\end{tabular}

1 https://www.cia.gov/library/publications/resources/the-world-factbook/geos/uk.html https://www.cia.gov/library/publications/resources/the-world-factbook/geos/gm.html https://www.cia.gov/library/publications/resources/the-world-factbook/geos/fr.html https://www.cia.gov/library/publications/resources/the-world-factbook/geos/ee.html

Table 1c: GDP Per Capita by Country (2015 estimated)

\begin{tabular}{|c|c|c|c|}
\hline Country & $\begin{array}{l}\text { GDP Total }{ }^{1} \\
\text { [in billions US\$] } \\
\text { (world rank) }\end{array}$ & $\begin{array}{l}\text { Annual GDP } \\
\text { Real Growth Rate } \\
\text { (world rank) }\end{array}$ & $\begin{array}{l}\text { Annual GDP } \\
\text { Per Capita } \\
\text { [in US\$] } \\
\text { (world rank) }\end{array}$ \\
\hline European Union & $\begin{array}{l}19,180 \\
(2)\end{array}$ & $\begin{array}{l}2.20 \% \\
(134)\end{array}$ & $\begin{array}{l}37,800 \\
(46)\end{array}$ \\
\hline United Kingdom & $\begin{array}{l}2,702 \\
(10)\end{array}$ & $\begin{array}{l}2.20 \% \\
(133)\end{array}$ & $\begin{array}{l}41,200 \\
(39)\end{array}$ \\
\hline Germany & $\begin{array}{l}3,860 \\
(6)\end{array}$ & $\begin{array}{l}1.50 \% \\
(149)\end{array}$ & $\begin{array}{l}46,900 \\
(28)\end{array}$ \\
\hline France & $\begin{array}{l}2,666 \\
(11)\end{array}$ & $\begin{array}{l}1.30 \% \\
(157)\end{array}$ & $\begin{array}{l}41,200 \\
(38)\end{array}$ \\
\hline
\end{tabular}

${ }^{1}$ https://www.cia.gov/library/publications/resources/the-world-factbook/rankorder/2001rank.html ${ }^{2}$ https://www.cia.gov/library/publications/resources/the-world-factbook/rankorder/2003rank.html ${ }^{3}$ https://www.cia.gov/library/publications/resources/the-world-factbook/rankorder/2004rank.html

The EU, as of 2016 , has an unemployment rate of $9.5 \%$ as shown in Table 1 a. The individual countries comprising the EU have been challenged in recent years by 
the net immigration of people into their countries, placing strains on their social welfare systems and employment. This immigration issue, fostered by the EU's open borders policy, was critical in the 2016 vote by UK citizens to withdraw from the EU and potentially will have repercussions in upcoming elections such as in Germany.

The EU is diversified across all industry sectors. While all three countries are diversified across industry sectors, there are some differences in emphasis and strength. Germany is recognized as the world's largest and most technologically advanced manufacturer of industrial and chemical products (CIA World Fact Book, 2016). They are a major producer of machinery, vehicles, electronics, chemicals and household equipment, with significant investment in the related material industries of steel, iron, coal and cement. In terms of GDP composition by sector (Table 1b), Industry represents 30.2 percent of Germany's GDP, as compared to approximately 19 percent of the UK's and France's GDP. The economies of France and the UK are slightly more dependent on the services sector, with financial services an important contributor to the UK economy and tourism a leading industry in France.

All three countries have experienced positive real growth in GDP in recent years, with improvement seen in 2015 over the previous two years. The estimated Annual GDP Real Growth Rate in 2015 was 2.2 percent in the UK, 1.50 percent in Germany, and 1.1 percent in France, as shown in Table 1c. Germany is known to have a highly skilled labor force, and among the three nations has the highest percentage of its population employed in its labor force at 55.8 percent (as compared to the UK at 51.1 percent and France at 44.6 percent) and the lowest unemployment rate at 4.8 percent (versus 5.5 percent for the UK and 9.9 percent for France), as summarized in Table 1a.

Table 1d: Exports and Imports by Country (2015 estimated) $)^{1,2}$

\begin{tabular}{|c|c|c|c|c|c|c|}
\hline \multirow[b]{2}{*}{ Country } & \multicolumn{3}{|l|}{ EXPORTS } & \multicolumn{3}{|l|}{ IMPORTS } \\
\hline & $\begin{array}{l}\text { Total }^{1} \\
\text { [in billions US\$] } \\
\text { (world rank) } \\
\end{array}$ & $\begin{array}{l}\text { Major Export } \\
\text { Partners }\end{array}$ & $\begin{array}{l}\% \text { of } \\
\text { Total }\end{array}$ & $\begin{array}{l}\left.T^{T}\right|^{2} \\
\text { [in billions US\$] } \\
\text { (world rank) }\end{array}$ & $\begin{array}{l}\text { Major Import } \\
\text { Partners }\end{array}$ & $\begin{array}{l}\% \text { of } \\
\text { Total } \\
\end{array}$ \\
\hline $\begin{array}{l}\text { European } \\
\text { Union }^{3}\end{array}$ & $\begin{array}{l}2,259.0 \\
(1)\end{array}$ & $\begin{array}{l}\text { US } \\
\text { China } \\
\text { Switzerland }\end{array}$ & $\begin{array}{c}17.1 \% \\
8.5 \% \\
7.8 \%\end{array}$ & $\begin{array}{l}2,244.0 \\
(2)\end{array}$ & $\begin{array}{l}\text { China } \\
\text { US } \\
\text { Russia } \\
\text { Switzerland }\end{array}$ & $\begin{array}{c}16.1 \% \\
11.4 \% \\
11.0 \% \\
5.9 \%\end{array}$ \\
\hline $\begin{array}{l}\text { United } \\
\text { Kingdom }\end{array}$ & $\begin{array}{l}436.2 \\
(11)\end{array}$ & $\begin{array}{l}\text { US } \\
\text { Germany } \\
\text { Switzerland } \\
\text { France }\end{array}$ & $\begin{array}{l}14.6 \% \\
10.1 \% \\
7.0 \% \\
5 . \%\end{array}$ & $\begin{array}{l}627.7 \\
(6)\end{array}$ & $\begin{array}{l}\text { Germany } \\
\text { China } \\
\text { US } \\
\ldots \\
\text { France } \\
\end{array}$ & $\begin{array}{c}14.8 \% \\
9.8 \% \\
9.2 \% \\
5.8 \% \\
\end{array}$ \\
\hline Germany $^{3}$ & $\begin{array}{l}1,309.0 \\
(4)\end{array}$ & $\begin{array}{l}\text { US } \\
\text { France } \\
\text { UK }\end{array}$ & $\begin{array}{l}9.6 \% \\
8.6 \% \\
7.5 \%\end{array}$ & $\begin{array}{l}983.9 \\
(4)\end{array}$ & $\begin{array}{l}\text { Netherlands } \\
\text { France } \\
\text { China } \\
\ldots \\
\text { UKK }\end{array}$ & $\begin{array}{l}13.7 \% \\
7.6 \% \\
7.3 \% \\
\\
4.2 \% \\
\end{array}$ \\
\hline France $^{3}$ & $\begin{array}{l}510.5 \\
(7)\end{array}$ & $\begin{array}{l}\text { Germany } \\
\text { Spain } \\
\text { US } \\
\text { UK }\end{array}$ & $\begin{array}{l}15.9 \% \\
7.3 \% \\
7.2 \% \\
7.1 \%\end{array}$ & $\begin{array}{l}537.5 \\
(7)\end{array}$ & $\begin{array}{l}\text { Germany } \\
\text { Belgium } \\
\text { Italy } \\
\ldots \\
\text { UK }\end{array}$ & $\begin{array}{l}19.5 \% \\
10.7 \% \\
7.7 \% \\
\\
4.3 \% \\
\end{array}$ \\
\hline
\end{tabular}


${ }^{1}$ https://www.cia.gov/library/publications/resources/the-world-factbook/rankorder/2078rank.html

${ }^{2}$ https://www.cia.gov/library/publications/resources/the-world-factbook/rankorder/2087rank.html

${ }^{3}$ https://www.cia.gov/library/publications/resources/the-world-factbook/geos/uk.html,

https://www.cia.gov/library/publications/resources/the-world-factbook/geos/gm.html,

https://www.cia.gov/library/publications/resources/the-world-factbook/geos/fr.html

https://www.cia.gov/library/publications/resources/the-world-factbook/geos/ee.html

The EU ranks first in the world in exports ( $\$ 2,259$ billion) and second in the world on imports (\$2,244 billion) in imports The EU's largest trading partners are the US, China, and Switzerland for exports and the US, China, Russia, and Switzerland for imports. The EU, therefore, experienced a trade surplus in 2015 of $\$ 15$ billion. The economies of the largest three member nations of the EU are interdependent with countries within the EU and also have strong relationships with the US and China, as evidenced by the percentage of imports and exports flowing among them. As shown in Table 1d, Germany is the largest of the three with import trading partnerships with the Netherlands (13.7 percent), France (7.6\%) and the UK (4.2\%). Germany is also a major export trading partner to France $(8.6 \%)$ the UK, $(7.5 \%)$, and the Netherlands (6.5\%). Trade between Germany, France, and the UK and the US is also robust, especially in exports. Each country has the US as a top leading country as an exporting partner. In 2015 Germany had a trading surplus while France and the UK were net importers of goods and services.

\section{A Brief Description of Asian Economies}

The Asian economy is vast and comprises 48 diverse countries. By definition Russia and Turkey are in this category although they border the European continent and are usually considered Eastern Europe. The countries are further classified as Central Asia, East Asia, South Asia, Southeast Asia, and West Asia. In terms of GDP, excluding Russia and Turkey, the countries of China, India, Japan, Indonesia, and South Korea make up $19 \%$ of the total GDP.

The comparative statistics for China, India, Japan, Indonesia, and South Korea are provided in Tables 2a-2d. China and India rank first and second respectively in the world in population as well as Labor Force with Indonesia ranking fifth in both world population and labor force (Table 2a) China has a Gross Domestic Product (GDP) per capita of 19,300.0 billion dollars and is ranked first in the world. India has a GDP of 7.965 billion dollars and is ranked fourth in the world, with Japan at 4.830 billion in GDP and ranked fifth. Indonesia ranks ninth and South Korea fourteenth in the world in GDP (Table 2c) As the largest economies in South and Southeast Asia based on Gross Domestic Product (GDP), the countries of China, India, Japan, Indonesia, and South Korea have GDP per capita ratios that vary greatly with South Korea ranking fifteenth and Japan forty-third in the world while India is at $158^{\text {th }}$, Indonesia $131^{\text {st }}$, China $113^{\text {th }}$ in world ranking. 
Table 2a: Population, Growth Rate and Labor Force by Country (Asia) (2016 estimated)

\begin{tabular}{|l||l|l|l|l|l|}
\hline Country & $\begin{array}{l}\text { Population } \\
\text { [in millions } \\
\text { (world rank) }\end{array}$ & $\begin{array}{l}\text { Population }^{2} \\
\text { Growth Rate } \\
\text { (world rank) }\end{array}$ & $\begin{array}{l}\text { Labor Force } \\
\text { [in millions] } \\
\text { (world rank) }\end{array}$ & $\begin{array}{l}\text { Labor Force } \\
\text { as Percentage } \\
\text { of Population }\end{array}$ & $\begin{array}{l}\text { Unemployment } \\
\text { Rate } \\
\text { (world rank) }\end{array}$ \\
\hline \hline China & $\begin{array}{l}1,373.5 \\
(1)\end{array}$ & $\begin{array}{l}0.43 \% \\
(164)\end{array}$ & $\begin{array}{l}806.3 \\
(1)\end{array}$ & $58.7 \%$ & $\begin{array}{l}4.0 \% \\
(35)\end{array}$ \\
\hline \hline India & $\begin{array}{l}1,266.9 \\
(2)\end{array}$ & $\begin{array}{l}1.19 \% \\
(97)\end{array}$ & $\begin{array}{l}501.8 \\
(2)\end{array}$ & $39.6 \%$ & $\begin{array}{l}8.4 \% \\
(95)\end{array}$ \\
\hline Japan & $\begin{array}{l}(26.7 \\
(11)\end{array}$ & $\begin{array}{l}-0.19 \%) \\
(214)\end{array}$ & $\begin{array}{l}66.0 \\
(9)\end{array}$ & $52.1 \%$ & $\begin{array}{l}3.4 \% \\
(28)\end{array}$ \\
\hline Indonesia & $\begin{array}{l}258.2 \\
(5)\end{array}$ & $\begin{array}{l}0.89 \% \\
(126)\end{array}$ & $\begin{array}{l}122.5 \\
(5)\end{array}$ & $47.3 \%$ & $\begin{array}{l}6.2 \% \\
(71)\end{array}$ \\
\hline South Korea & $\begin{array}{l}(50.9 \\
(28)\end{array}$ & $\begin{array}{l}0.53 \% \\
(156)\end{array}$ & $\begin{array}{l}26.9 \\
(25)\end{array}$ & $52.8 \%$ & $\begin{array}{l}3.6 \% \\
(31)\end{array}$ \\
\hline
\end{tabular}

${ }^{1} \mathrm{https} / / /$ www.cia.gov/library/publications/resources/the-world-factbook/rankorder/2119rank.html

${ }^{2}$ https://www.cia.gov/library/publications/resources/the-world-factbook/rankorder/2002rank.html

${ }^{3}$ https://www.cia.gov/library/publications/resources/the-world-factbook/rankorder/2095rank.html

${ }^{4}$ https://www.cia.gov/library/publications/resources/the-world-factbook/rankorder/2129rank.html

China has moved from a closed, strictly communist system, to a more market oriented economy that plays a major role in the global economy over the last 40 plus years. It is the leading world's exporter and as of 2015 the largest economy in the world. For many years China linked its currency, the renminbi, to the US dollar, however in 2005, moved to an exchange rate system that references a basket of currencies.

The rapid growth and change in the Chinese economy does not mitigate the many challenges that the Chinese government faces economically and socially. Expectations of a growing middle class, social issues such as corruption and economic crimes, containing environmental damage, are a few of the challenges (CIA World Fact Book, 2016).

China, has moved from a closed, strictly communist system, to a more market oriented economy that plays a major role in the global economy over the last 40 plus years. It is the leading world's exporter and as of 2015 the largest economy in the world. For many years China linked its currency, the renminbi, to the US dollar, however in 2005, moved to an exchange rate system that references a basket of currencies.

Table 2b: GDP Composition by Sector of Origin (2015 estimated) ${ }^{1}$

\begin{tabular}{|c||l|l|l|}
\hline & & & \\
Country & $\begin{array}{l}\text { Agriculture } \\
\text { Percent of Total GDP }\end{array}$ & $\begin{array}{l}\text { Industry } \\
\text { Percent of Total GDP }\end{array}$ & $\begin{array}{l}\text { Services } \\
\text { Percent of Total GDP }\end{array}$ \\
\hline \hline China & $8.9 \%$ & $40.9 \%$ & $50.2 \%$ \\
\hline India & $17.0 \%$ & $29.7 \%$ & $45.0 \%$ \\
\hline Japan & $1.2 \%$ & $27.5 \%$ & $71.3 \%$ \\
\hline Indonesia & $14.0 \%$ & $41.3 \%$ & $44.7 \%$ \\
\hline South Korea & $2.3 \%$ & $38.0 \%$ & $59.7 \%$ \\
\hline
\end{tabular}

${ }^{1} \mathrm{https} / / /$ www.cia.gov/library/publications/resources/the-world-factbook/geos/ch.html 
https://www.cia.gov/library/publications/resources/the-world-factbook/geos/in.html https://www.cia.gov/library/publications/resources/the-world-factbook/geos/ja.html https://www.cia.gov/library/publications/resources/the-world-factbook/geos/id.html https://www.cia.gov/library/publications/resources/the-world-factbook/geos/ks.html

Table 2c: GDP Per Capita by Country (2015 estimated)

\begin{tabular}{|l||l|l|l|}
\hline & & & \\
& GDP Total & Annual GDP \\
Country & [in billions US\$] & $\begin{array}{l}\text { Annual GDP } \\
\text { Real Growth Rate } \\
\text { (world rank) }\end{array}$ & $\begin{array}{l}\text { Per Capita } \\
\text { [in US } \$ \text { ] } \\
\text { (world rank) }\end{array}$ \\
\hline \hline China $^{1}$ & 19,300 & $6.9 \%$ & 14,100 \\
& $(1)$ & $(16)$ & $(113)$ \\
\hline India $^{2}$ & 7,965 & $7.3 \%$ & 6,200 \\
& $(4)$ & $(10)$ & $(158)$ \\
\hline Japan $^{3}$ & 4,830 & $0.5 \%$ & 38,100 \\
& $(5)$ & $(187)$ & $(43)$ \\
\hline Indonesia $^{4}$ & 2,843 & $4.8 \%$ & 11,100 \\
& $(9)$ & $(51)$ & $(131)$ \\
\hline South Korea & 5 & $2.6 \%$ & 36,500 \\
& 1,849 & $(115)$ & $(15)$ \\
\hline
\end{tabular}

${ }^{1}$ https://www.cia.gov/library/publications/resources/the-world-factbook/geos/ch.html

${ }^{2}$ https://www.cia.gov/library/publications/resources/the-world-factbook/geos/in.html

${ }^{3} \mathrm{https}$ //www.cia.gov/library/publications/resources/the-world-factbook/geos/ja.html

${ }^{4}$ https://www.cia.gov/library/publications/resources/the-world-factbook/geos/id.html

${ }^{5} \mathrm{https}$ ///www.cia.gov/library/publications/resources/the-world-factbook/geos/ks.html

The rapid growth and change in the Chinese economy does not mitigate the many challenges that the Chinese government faces economically and socially. Expectations of a growing middle class, social issues such as corruption and economic crimes, containing environmental damage are a few of the challenges (CIA World Fact Book, 2016).

India, second in the world in population and fourth in the world in GDP, as noted above, has a diverse economy that includes a diverse range of modern industries and service organizations. The large educated English-speaking population has enabled India to become a major exporter of information technology services, business outsourcing services, and software workers. Economic growth has benefited from economic liberalization measures that include industrial deregulation, privatization of state-owned enterprises, and reduced controls on foreign trade and investment, over the last quarter century. The Indian economy does struggle currently with an $8.4 \%$ unemployment rate (the highest among the five Asian countries compared) and societal and infrastructural needs. Rising macroeconomic imbalances in India and improving economic conditions in Western countries has led investors to shift capital away from India, prompting a sharp depreciation of the rupee in recent years. 
Table 2d: Exports and Imports by Country (2015 estimated)

\begin{tabular}{|c|c|c|c|c|c|c|}
\hline \multirow[b]{2}{*}{ Country } & \multicolumn{3}{|l|}{ EXPORTS } & \multicolumn{3}{|l|}{ IMPORTS } \\
\hline & $\begin{array}{l}\text { Total }^{1} \\
\text { [in billions } \\
\text { US\$] } \\
\text { (world rank) }\end{array}$ & $\begin{array}{l}\text { Major Export } \\
\text { Partners }\end{array}$ & $\begin{array}{l}\% \text { of } \\
\text { Total }\end{array}$ & $\begin{array}{l}\text { Total }^{2} \\
\text { [in billions } \\
\text { US\$] } \\
\text { (world rank) }\end{array}$ & $\begin{array}{l}\text { Major Import } \\
\text { Partners }\end{array}$ & $\begin{array}{l}\% \text { of } \\
\text { Total }\end{array}$ \\
\hline China $^{3}$ & $\begin{array}{l}2,143.0 \\
(2)\end{array}$ & $\begin{array}{l}\text { US } \\
\text { Hong Kong } \\
\text { Japan } \\
\text { South Korea }\end{array}$ & $\begin{array}{c}18.0 \% \\
14.0 \% \\
6.0 \% \\
4.5 \%\end{array}$ & $\begin{array}{l}1,575.0 \\
(3)\end{array}$ & $\begin{array}{l}\text { South Korea } \\
\text { US } \\
\text { Japan } \\
\text { Germany }\end{array}$ & $\begin{array}{c}10.9 \% \\
9.0 \% \\
8.9 \% \\
5.5 \%\end{array}$ \\
\hline India $^{3}$ & $\begin{array}{l}272.4 \\
(20)\end{array}$ & $\begin{array}{l}\text { US } \\
\text { UAR } \\
\text { Hong Kong }\end{array}$ & $\begin{array}{l}15.2 \% \\
14.4 \% \\
4.6 \%\end{array}$ & 409.2 & $\begin{array}{l}\text { China } \\
\text { Saudi Arabia } \\
\text { UAR } \\
\text { US }\end{array}$ & $\begin{array}{l}15.5 \% \\
5.5 \% \\
5.4 \% \\
5.2 \%\end{array}$ \\
\hline $\operatorname{Japan}^{3}$ & $\begin{array}{l}622.0 \\
(5)\end{array}$ & $\begin{array}{l}\text { US } \\
\text { China } \\
\text { South Korea } \\
\text { Hong Kong }\end{array}$ & $\begin{array}{c}20.2 \% \\
17.5 \% \\
7.1 \% \\
5.6 \%\end{array}$ & $\begin{array}{l}627.3 \\
(6)\end{array}$ & $\begin{array}{l}\text { China } \\
\text { US } \\
\text { Australia } \\
\text { South Korea }\end{array}$ & $\begin{array}{c}24.8 \% \\
10.5 \% \\
5.4 \% \\
4.1 \%\end{array}$ \\
\hline Indonesia $^{3}$ & $\begin{array}{l}148.4 \\
(31)\end{array}$ & $\begin{array}{l}\text { Japan } \\
\text { US } \\
\text { China }\end{array}$ & $\begin{array}{c}12.0 \% \\
10.8 \% \\
10.0 \%\end{array}$ & 135.1 & $\begin{array}{l}\text { China } \\
\text { Singapore } \\
\text { Japan } \\
\text { South Korea }\end{array}$ & $\begin{array}{l}20.6 \% \\
12.6 \% \\
9.3 \% \\
5.9 \%\end{array}$ \\
\hline South Korea ${ }^{3}$ & $\begin{array}{l}548.8 \\
(6)\end{array}$ & $\begin{array}{l}\text { China } \\
\text { US } \\
\text { Hong Kong } \\
\text { Vietnam } \\
\end{array}$ & $\begin{array}{l}26.0 \% \\
13.3 \% \\
5.8 \% \\
5.3 \% \\
\end{array}$ & $\begin{array}{l}428.5 \\
(10)\end{array}$ & $\begin{array}{l}\text { China } \\
\text { Japan } \\
\text { US } \\
\text { Germany }\end{array}$ & $\begin{array}{l}20.7 \% \\
10.5 \% \\
10.1 \% \\
4.8 \% \\
\end{array}$ \\
\hline
\end{tabular}

${ }^{1}$ https://www.cia.gov/library/publications/resources/the-world-factbook/rankorder/2078rank.html

${ }^{2}$ https://www.cia.gov/library/publications/resources/the-world-factbook/rankorder/2087rank.html

${ }^{3} \mathrm{https}: / / \mathrm{ww}$.cia.gov/library/publications/resources/the-world-factbook/geos/ch.html https://www.cia.gov/library/publications/resources/the-world-factbook/geos/in.html https://www.cia.gov/library/publications/resources/the-world-factbook/geos/ja.html https://www.cia.gov/library/publications/resources/the-world-factbook/geos/id.html https://www.cia.gov/library/publications/resources/the-world-factbook/geos/ks.html

Recently there has been a rebound in the growth of the economy and the outlook for India's long-term growth. It is said to be moderately positive due in large part to a young population, investment rates, and increasing integration into the global economy (CIA World Fact Book, 2016).

Japan, eleventh in the world in population and fifth in GDP, has prospered with over three decades of overall real economic growth. With some slowing in the 1990s, government stimulus spending helped the economy recover in late 2009 and 2010, and again after the devastation of the earthquake and tsunami in 2011. Japan in 2016 has an unemployment rate of $3.4 \%$ (Table $2 a$ ).

Japan enjoyed a sharp uptick in growth in 2013 as a result of the government's "Three Arrows" economic revitalization agenda - dubbed "Abenomics" -of monetary easing, "flexible" fiscal policy, and structural reform. In 2015, "Three Arrows" was revised to raise nominal GDP by $20 \%$ to 600 trillion yen by 2020 , stem population decline by raising the fertility rate, and provide more support for workers with children 
and aging relatives. In October 2015, Japan and 11 other trading partners including Australia, Brunei, Canada, Chile, Malaysia, Mexico, New Zealand,, Peru, Singapore, the United States, and Vietnam, reached an agreement on the Trans-Pacific Partnership (TTP), a pact that promises to open Japan's economy to increased foreign competition and create new export opportunities for Japanese businesses. However, as of this time, the impact of TTP is under uncertainty given that the United States is currently poised to back out of this agreement. Some analysts say that this will give China an opportunity that the United States would have filled.

Led by the Bank of Japan's aggressive monetary easing, Japan is working in ending deflation, but demographic decline - a low birthrate and an aging, shrinking population - poses a major long-term challenge for the economy (CIA World Fact Book, 2016).

Indonesia ranks fifth in world population and ninth in GDP. It is the economy in region of Southeast Asia. Their economy has experienced a decline in growth since 2012 as their commodities export boom declined. During the recent global financial crisis, Indonesia joined China and India as the only G20 members posting growth. Indonesia's annual budget deficit is capped at $3 \%$ of GDP, and the Government of Indonesia lowered its debt-to-GDP ratio from a peak of $100 \%$ shortly after the Asian financial crisis in 1999 to less than 25\% today. Fitch and Moody's upgraded Indonesia's credit rating to investment grade in December 2011. The Indonesian currency is the rupiah. (CIA World Fact Book, 2016).

Indonesia's economy is impacted by struggles with poverty and unemployment at $6.2 \%$ (Table 2a), inadequate infrastructure, corruption, a complex regulatory environment, and unequal resource distribution among its regions. Indonesia, with the nine other ASEAN members, will continue to move towards participation in the ASEAN Economic Community, though full implementation of economic integration has not yet materialized.

South Korea ranks twenty-eighth in the world in population and fourteenth in GDP. It has an unemployment rate of $3.6 \%$ (Table $2 a$ ) comparable to Japan. The South Korean economy grew rapidly in the 1960s. During this period, they transformed themselves from a poor developing country into an economy of world ranking in GDP and has become a leader in the world in both exports (sixth in the world) and imports (tenth in the world) (Table 2d).

The South Korean economy has some long-term challenges that include a rapidly aging population, inflexible labor market, dominance of large conglomerates (chaebols), and the heavy reliance on exports, which comprise about half of GDP. Structural reforms are currently being implemented by the government. The South Korean currency is the won.

\section{Methodology and Data}

Multiple Discriminant Analysis - MDA (see, e.g., Altman, 1968; Stevens, 1973; Belkaoui, 1978) and Multivariate Analysis of Variance - MANOVA (see, e.g., 
Hutchinson et al., 1988; Meric et al., 1991) are the two multivariate techniques most commonly used in previous studies to compare the financial characteristics of different groups of firms. In this study, we use the MANOVA technique to compare the financial characteristics of European and Asian manufacturing firms. Detailed information about the MANOVA technique can be found in Marascuilo and Levin (1983) and Johnson and Wichern (2007).

Financial ratios are generally used in empirical studies to compare the financial characteristics of different groups of firms. The financial ratio data used in this study were obtained from the 2015 year-end financial statements of the firms. Manufacturing industries with SIC codes between 2000-3999 are covered in the study. The study includes all European and Asian manufacturing firms in the Research Insight/Global Vintage database with no missing financial data. Our sample contains 1,219 European and 8,620 Asian manufacturing firms. We use the financial ratios presented in Table 3 as measures of firm financial characteristics in the comparisons.

\section{Table 3: Financial Ratios Used in the Study as Measures of Firm Financial Characteristics}

Financial Ratio

\section{Liquidity}

Current Ratio

Quick (Acid-Test) Ratio

Asset Management

Average Collection Period

Inventory Turnover

Total Assets Turnover

Financial Leverage

Debt/Equity Ratio

Profitability

Net Profit Margin

Return on Assets

Return on Equity

Growth

Sales Growth Rate
Financial Ratio Definition

Current Assets / Current Liabilities

(Current Assets - Inventories) / Current Liabilities

Accounts Receivable / Daily Credit Sales

Sales / Inventories

Sales / Total Assets

Total Debt / Common Equity

Net Income / Sales

Net Income / Total Assets

Net Income / Common Equity

Annual Percentage Sales Growth rate

\section{Empirical Findings}

Our MANOVA test results are presented in Table 4. The multivariate F-value test statistic in the table indicates that the overall financial characteristics of European 
and Asian manufacturing firms are significantly different at the 1-percent level. The univariate F-value test statistics indicate that the financial characteristics of European and Asian manufacturing firms are significantly different in terms of liquidity, asset management, financial leverage, net profit margin, return on assets, and sales growth rate.

Table 4: MANOVA: European Manufacturing Firms vs. Asian Manufacturing Firms

\begin{tabular}{|c|c|c|c|c|}
\hline \multirow[b]{2}{*}{ Financial Ratios } & \multicolumn{2}{|c|}{ Means and Standard Deviations } & \multicolumn{2}{|c|}{ Univariate Statistics } \\
\hline & Europe & Asia & F-Value & P-Value \\
\hline \multicolumn{5}{|l|}{ Liquidity } \\
\hline Current Ratio & $\begin{array}{c}2.00 \\
(1.32)\end{array}$ & $\begin{array}{c}2.51 \\
(3.08)\end{array}$ & $31.8^{\star \star}$ & 0.00 \\
\hline Quick (Acid-Test) Ratio & $\begin{array}{c}1.32 \\
(1.13)\end{array}$ & $\begin{array}{c}1.77 \\
(2.66)\end{array}$ & $33.2^{* *}$ & 0.00 \\
\hline \multicolumn{5}{|l|}{ Asset Management } \\
\hline Average Collection Period & $\begin{array}{c}76.7 \\
(42.9)\end{array}$ & $\begin{array}{c}87.9 \\
(56.1)\end{array}$ & $44.7^{* \star}$ & 0.00 \\
\hline Inventory Turnover & $\begin{array}{c}5.88 \\
(8.59)\end{array}$ & $\begin{array}{c}7.76 \\
(26.7)\end{array}$ & $5.97^{*}$ & 0.02 \\
\hline Fixed Assets Turnover & $\begin{array}{r}11.2 \\
(23.6)\end{array}$ & $\begin{array}{c}6.85 \\
(27.0)\end{array}$ & $29.2^{* *}$ & 0.00 \\
\hline Total Assets Turnover & $\begin{array}{c}1.02 \\
(0.48)\end{array}$ & $\begin{array}{c}0.93 \\
(0.55)\end{array}$ & $26.6^{\star *}$ & 0.00 \\
\hline
\end{tabular}

Financial Leverage

\begin{tabular}{|c|c|c|c|c|}
\hline Debt/Equity Ratio & $\begin{array}{c}1.36 \\
(1.50) \\
\end{array}$ & $\begin{array}{c}2.27 \\
(3.48) \\
\end{array}$ & $81.8^{* *}$ & 0.00 \\
\hline \multicolumn{5}{|l|}{ Profitability } \\
\hline Net Profit Margin & $\begin{array}{r}3.18 \% \\
(10.2 \%)\end{array}$ & $\begin{array}{r}4.80 \% \\
(10.0 \%)\end{array}$ & $28.0^{\star *}$ & 0.00 \\
\hline Return on Assets & $\begin{array}{c}3.36 \% \\
(7.42 \%)\end{array}$ & $\begin{array}{c}3.79 \% \\
(6.28 \%)\end{array}$ & $4.70^{*}$ & 0.03 \\
\hline Return on Equity & $\begin{array}{c}6.90 \% \\
(15.9 \%)\end{array}$ & $\begin{array}{c}6.38 \% \\
(12.3 \%)\end{array}$ & 1.77 & 0.18 \\
\hline
\end{tabular}

Growth

\begin{tabular}{|c|c|c|c|c|}
\hline Sales Growth Rate & $\begin{array}{c}4.22 \% \\
(13.5 \%)\end{array}$ & $\begin{array}{c}7.15 \% \\
(21.2 \%)\end{array}$ & $22.1^{\text {** }}$ & 0.00 \\
\hline Multivariate Statistics: & & & $22.1^{* *}$ & 0.00 \\
\hline
\end{tabular}

$† \quad$ The figures in parentheses are the standard deviations.

**, * indicate that the difference is significant at the 1-percent and 5-percent levels, respectively. 


\section{Liquidity}

Both current ratio and quick (acid-test) ratio are significantly higher in Asian firms than in European firms. This implies that Asian firms are better able to meet their maturing obligations compared with European firms (i.e., there is less liquidity risk in Asian firms than in European firms).

\section{Asset Management}

All four asset management ratios are significantly different in European and Asian Manufacturing firms. The univariate F-value test statistics indicate that the most significant difference is in terms of average collection period and the least significant difference is in terms of inventory turnover. European firms have more efficient accounts receivable management. It takes significantly shorter for European firms to collect their accounts receivable compared with Asian Firms. However, Asian firms are able to achieve a significantly higher inventory turnover compared with European firms. European firms also appear to have a higher fixed assets turnover and a higher total assets turnover compared with Asian manufacturing firms.

\section{Financial Leverage}

The univariate F-value test statistics indicate that the most significant difference between European and Asian manufacturing firms is in terms of financial leverage. Asian firms appear to use more financial leverage (more debt financing) compared with European firms. This implies that Asian firms have more financial risk (bankruptcy risk) compared with European firms.

\section{Profitability}

Return on equity is not significantly different in European and Asian firms. However, net profit margin and return on assets are significantly higher in Asian firms than in European firms. The univariate F-value statistics and their significance levels indicate that there is more significant difference between Asian and European firms in terms of net profit margin than in terms of return on assets. Lower labor costs in Asia may be an important factor that can keep production costs significantly lower and net profit margin significantly higher in Asian firms compared with European firms. European firms having a significantly higher total assets turnover reduces the significance of the difference between the two groups of firms in terms of return on assets.

\section{Sales Growth Rate}

Annual sales growth rate is significantly higher in Asian manufacturing firms than in European manufacturing firms. This implies that Asian manufacturing firms are able to grow significantly faster compared with European manufacturing firms. 


\section{Summary and Conclusions}

Comparing the financial characteristics of firms in different countries has been a popular research methodology in finance. General financial characteristics of European and Asian manufacturing firms have never been compared in previous literature. In this paper, we undertake such a study with the MANOVA (Multivariate Analysis of Variance) technique and data from the Research Insight/Global Vintage database at the end of 2015. Our findings in this study may provide valuable insights for financial managers in all countries and global investors.

We find that Asian manufacturing firms tend to have significantly higher liquidity ratios (i.e., Asian firms have less liquidity risk) compared with their European counterparts. However, Asian manufacturing firms have significantly higher debt/equity ratios (i.e., Asian firms have greater bankruptcy risk) compared with European manufacturing firms.

We find that European manufacturing firms have more efficient accounts receivable management compared with Asian Manufacturing firms. It takes considerable shorter for European manufacturing firms to collect their accounts receivable compared with Asian manufacturing firms. European firms also tend to have higher fixed assets turnover and total assets turnover rates. However, Asian firms tend to have have higher inventory turnover rates.

There is no significant difference between European and Asian returns on equity. However, Asian manufacturing firms have significantly higher net profit margins and returns on assets compared with European manufacturing firms. The difference between Asian and European net profit margins is statistically more significant than the difference between their returns on assets. Low labor costs is an important factor keeping manufacturing costs lower and net profit margins higher in Asian firms. The significantly higher total assets turnover rate in European manufacturing firms reduces the significance of the difference between Asian and European returns on assets.

\section{References}

Altman, E. I. 1968. Financial Ratios, Discriminant Analysis, and the Prediction of Corporate Bankruptcy. Journal of Finance, 23 (4): 589-609.

Beaver, W. H. 1968. Alternative Financial Ratios as Predictors of Failure. Accounting Review, 43 (1): 113-122.

Belkaoui, A. 1978. Financial Ratios as Predictors of Canadian Takeovers. Journal of Business Finance and Accounting, 5 (1): 93-108.

CIA, World Fact Book. 2016. https://www.cia.gov/library/publications/resources/the-worldfactbook/geos/ee.html

Dambolena, I. G., and S. J. Khoury. 1980. Ratio Stability and Corporate Failure. Journal of Finance, 35 (4): 1017-1026.

Deakin, E. B. 1972. A Discriminant Analysis of Predictors of Business failure. Journal of Accounting Research, 10 (1): 167-179. 
Edmister, R. O. 1972. An Empirical Test of Financial Ratio Analysis for Small Business Failure Prediction. Journal of Financial and Quantitative Analysis, 7 (2): 1477-1493.

Hutchinson, P., I. Meric, and G. Meric. 1988. The Financial Characteristics of Small Firms which Achieve Quotation on the UK Unlisted Securities Market. Journal of Business Finance and Accounting, 15 (1): 9-19.

Johnson, R. D., and D. W. Wichern. 2007. Applied Multivariate Statistical Analysis, $6^{\text {th }}$ ed. Englewood Cliffs, NJ: Prentice Hall.

Kester, W. C. 1986. Capital and Ownership Structure: A Comparison of United States and Japanese Manufacturing Firms. Financial Management, 15 (1): 5-16.

Marascuilo, L. A., and J. R. Levin. 1983. Multivariate Statistics in the Social Sciences. Monterey, California: Brooks/Cole Publishing Company.

Meric, G., J. T. Bentley, W. C. Mccall, and I. Meric. 2016. A Comparison of the Financial Characteristics of U.S. and European Manufacturing Firms. Studies in Business and Economics, 11 (2): 58-67.

Meric, G., L. Kyj, C. Welch, and I. Meric. 2000. A Comparison of the Financial Characteristics of Japanese Kieretsu-Affiliated and Independent Firms. Multinational Business Review, 8 (2): 26-30.

Meric, G., S. S. Leveen, and I. Meric. 1991. The Financial Characteristics of Commercial Banks Involved in Interstate Acquisitions. Financial Review, 26 (1): 75-90.

Meric, G., and I. Meric. 1992. A Comparison of the Financial Characteristics of Listed and Unlisted Companies. Mid-Western Journal of Business and Economics, 7 (1): 19-31.

Meric, I., H. E. Gishlick, C. W. McCall, and G. Meric. 2003. A Comparison of the Financial Characteristics of U.S. and Canadian Manufacturing Firms. Midwestern Business and Economic Review, 31 (1): 25-33.

Meric, I., and G. Meric. 1989. A Comparison of the Financial Characteristics of U.S. and Japanese Manufacturing Firms. Financial Management-FM Letters-, 18 (4): 9-10.

Meric, I., and G. Meric. 1994. A Comparison of the Financial Characteristics of United States and Japanese Manufacturing Firms. Global Finance Journal, 5 (1): 205-218.

Moyer, R. C. 1977. Forecasting Financial Failure: A Re-examination. Financial Management, 6 (1): 11-17.

Rege, U. P. 1984. Accounting Ratios to Locate Take-over Targets. Journal of Business Finance and Accounting, 11 (3): 301-311.

Stevens, D. L. 1973. Financial Characteristics of Merged Firms: A Multivariate Analysis. Journal of Financial and Quantitative Analysis, 8 (2): 149-158.

Wald, J. K. 1999. How Firm Characteristics Affect Capital Structure: An International Comparison. Journal of Financial Research, 22 (2): 161-187. 